\title{
A cognitive semantic approach to L2 learning of phrasal verbs
}

\section{Brian Strong}

\author{
University of Victoria PhD \\ candidate
}

\begin{abstract}
This quasi-experimental study investigated the contributions of a paired-associate learning method and a semantic analysis method for enhancing Japanese EFL learners' knowledge of phrasal verbs. In addition, since dual coding theory argues that basic image schemas of the orientation of particles create opportunities for deeper memory traces, a third treatment was included. It consisted of a semantic analysis along with basic pictures showing the direction of a trajectory in relation to a landmark. The results of the three treatments revealed participants who received the semantic analysis and those who received the semantic analysis plus basic pictures treatment outperformed the paired-associate group on the test. Based on the initial findings, it appears a semantic analysis approach is an effective teaching method that should be used to help learners overcome the confusion experienced when using phrasal verbs.

本論では準実験的研究法を使用し、日本人英語学習者の句動詞 に関する語彙知識強化における、対連合学習法 (Paired-Associate Learning Method) と意味論的分析学習法 (Semantic Analysis Method) の貢献度を調查した。さらに、二重符号化理論 (Dual Coding Theory) に基づく主張、すなわち、方向性を示す副詞不変化詞の基本的 イメージスキーマによってより深い記憶定着の機会が与えられるという 論に基づき、第3の方法を設定した。これは、意味論的分析と共に、目標 物と関係づけられた移動軌跡の方向性を示すイメージを与えるものであ る。以上 3 種類の方法を行った後、事後テストと遅延事後テストにおいて 語彙記憶の保持を測定した結果、意味論的分析を受けた群および、意味 論的分析に加えイメージを与えられた被験者群で、対連合学習法の被験 者群を上回る結果が示された。この初期調査の結果、意味論的分析が、 学習者が句動詞を使用する際に経験する混同を克服する助けとなる効果 的な教授法であることが示唆された。
\end{abstract}

rman and Warren (2009, p. 50) suggest that $55 \%$ of any text will consist of formulaic language. This estimate may be reasonably accurate considering that corpus linguistics researchers are finding patterns of idiomatic sequences used repeatedly throughout corpora. The idea that language use is largely formulaic and language acquisition involves a great deal of formulaicity is becoming a prevalent view in many fields of research. This paper very briefly reviews an experiment on teaching and learning phrasal verbs, which form a subset of formulaic language. The motivations for this experiment

\section{SIG Spotlight: Vocab SIG}

The JALT Vocabulary SIG provides a venue for the discussion and research into second language vocabulary acquisition and assessment, particularly as they pertain to language education in Japan. Its activities include holding an annual symposium, attracting some of the biggest names in vocabulary research worldwide, as well as producing two publications; an annual journal entitled Vocabulary Learning and Instruction (VLI), and a biannual bulletin titled Vocabulary Education and Research Bulletin (VERB). The articles range from theoretical frameworks to pedagogy, providing a wonderful mix of theory and teaching applications, all while maintaining a central focus on vocabulary. In addition, the SIG contains some of the wordiest members you are likely to meet, who are always up for a good time and discussion on (non)vocabulary-related concepts and ideas. Contact the SIG at <jaltvocab@gmail.com> for more information.

center on the fact that phrasal verbs remain largely problematic for many Japanese learners of English and that this is partly attributable to the little attention given to teaching phrasal verbs in the classroom.

Learning phrasal verbs is an enduring source of difficulty for many Japanese learners of English. The confusion may be largely attributable to the fact that English lexicalizes orientational schemas differently from Japanese. That is, English encodes orientational spatial senses in particles whereas Japanese encodes these senses in the verb itself (Yasuda, 2010, p. 251). Learners unaware of the special constructional contribution of particles and prepositions to the main verb may believe that phrasal verbs are arbitrary idiomatic expressions and regard rote memorization as the main strategy of learning phrasal verbs (Side, 1990). Farsani, Moinzadeh, and Tavakoli (2012) point out that this misconception has also led teachers and textbook writers to promote memorization strategies of learning phrasal verbs.

It appears that for many Japanese learners of English, the chief strategy for learning phrasal verbs is through rote memorization, where L1 
translations accompany target phrasal verbs. This piecemeal approach makes learning phrasal verbs a daunting task and tends to result in many learners underusing or incorrectly using phrasal verbs. An alternative strategy proposes raising learners' awareness of the orientational senses of prepositions and particles. This approach reflects cognitive linguistic principles of embodied cognition that highlight the fact that prepositions and particles have extended meanings that trace back to our experiences with our bodies, the environment, and the interaction between them (Lakoff \& Johnson, 1980).

\section{Aims and methods}

The aim of this quasi-experimental study was to investigate three methods of learning phrasal verbs. The 77 participants in this study were second-year Japanese science majors learning English as part of a compulsory 2-year program at a Japanese university. Prior to the experiment, all the participants had spent at least seven years learning English and, to ensure they were reasonably equally proficient in English, their TOEIC scores were collected, analyzed, and outliers were eliminated. In addition, a vocabulary test was administered to assess the participants' vocabulary breadth. Using Schmitt et al.'s (2001) Version 2 of the Vocabulary Levels Test indicated that the participants had receptive knowledge of a large number of the 2,000 most frequent word families $(\mathrm{M}=23.96 / 30)$, with a weaker grasp of words occurring at the 3,000word level $(\mathrm{M}=19.57 / 30)$ and at the 5,000-word level $(M=15.36 / 30)$. Based on the results, it was determined that the participants had a lowintermediate level of English that allows them to have a functional but limited proficiency. The frequencies of all the words occurring on the test were analyzed using VocabProfile <lextutor.ca $>$. The results showed that over $96 \%$ of the words occurred within the 2000 frequency band of the $\mathrm{BNC}$. The remainder of the words tended to be proper nouns or Japanese cognates. Thus, it is assumed that the participants would be familiar with nearly all of the words on the test.

This study focused its investigation on the particles up, down, out and off. For every particle, four verbs were selected, amounting to 16 phrasal verbs used for the treatment. The four particles were chosen for two reasons: (1) they are considered the most frequently occurring particles (Rudzka-Ostyn, 2003); and (2) the duration of the treatment was scheduled for 10 minutes only.
The participants were placed into three groups and each group received a different approach to learning the 16 phrasal verbs. Considering paired-associate learning is one of the most effective methods of learning single word items, it was hypothesized that it would also facilitate phrasal verb learning. The paired-associate learning group received a single sheet of paper in which the 16 phrasal verbs were presented in an L2-L1 format and were listed alphabetically. The treatment lasted 10 minutes and the 26 participants were instructed to ask the teacher if they had any questions about the items anytime during the treatment.

In a number of cognitive linguistics studies, a semantic analysis approach has contributed to participants learning multiword units. In this study, a semantic analysis of the contribution of the four particles was conducted for duration of 5 minutes. During this time, 24 participants received brief semantic instruction regarding the meaning of the four particles and how their prototypical meanings contribute to the meaning of the main verb. They were also encouraged to think about how these particles would be used in contexts. The semantic instruction encouraged the participants to understand the semantic relationship between the verb-particle constructions rather than to view the phrasal verbs as a single unit. The semantic analysis group received a single sheet of paper in which the phrasal verbs were grouped according to the particles and their prototypical meanings were provided such as up means to "move to a higher location." The remaining 5 minutes of the 10 -minute treatment were devoted to independent review and study of the materials.

Dual coding theory states that pairing semantic information with a mental representation creates an additional pathway for recollecting information (Boers, Piriz, \& Eyckmans, 2009). To investigate the effects of pairing a schematic image of the prototypical meanings of the four particles along with a semantic analysis, 27 participants received the same material as the semantic analysis group with the addition of basic schema pictures and the semantic instruction made frequent reference to the pictures. The instruction lasted 5 minutes and the participants spent the remaining 5 minutes in independent review and study of the materials. Based on the above three methods of learning phrasal verbs, the following hypotheses were formulated: 
1. The three groups will score equally well on the 32 exposed phrasal verbs.

2. The three groups will score differently on the 32 unexposed phrasal verbs.

The phrasal verbs were embedded in short contextual sentences except a blank space appeared in place of the particle. The participants were to select the correct particle from a list of the four target particles and if they did not know they were instructed to check the I don't know option. The particle gap-fill test taps into participants receptive knowledge of verb + particle combinations. Two sentences were created for each of the exposed phrasal verbs, resulting in 32 questions for the 16 exposed phrasal verbs. To investigate whether the participants would be able to apply learning from the treatment to new phrasal verbs with the same particle, an additional 16 unexposed phrasal verbs were included and two sentences were created for each of the 16 unexposed phrasal verbs, amounting to 32 questions. In total, the test consisted of 64 questions for $16(16 \times 2=32)$ exposed and $16(16 \times 2=32)$ unexposed phrasal verbs. The questions were randomly organized on the test.

\section{Results}

The results of the test can be found in Tables 1 and 2. Since the data do not violate assumptions of ANOVA, it was run on the test scores of the unexposed and exposed phrasal verbs for the three experimental groups to answer the hypotheses. To answer the first hypothesis, a one-way ANOVA revealed the scores did not differ across the three groups, $F(2,74)=.893, p=.414$. Since there are no reported statistical differences on the scores, no post hoc tests were followed up. To answer the second hypothesis, a one-way ANOVA revealed the scores differed significantly across the three groups, $F(2,74)=16.445, p=.001, \eta_{p}{ }^{2}$ $=.368$. Fisher's LSD post hoc tests revealed that the paired-associate group's score was lower than the semantic analysis group's $(p<.001)$ and lower than the semantic analysis + image schema group's $(p=.001)$. However, there was no statistically significant difference between scores for the semantic analysis group and the semantic analysis + image schema group $(p<.656)$.

\section{Discussion and conclusion}

The results indicate that the three experimental groups scored equally well on the 32 exposed phrasal verbs, suggesting that all three treatments were equally effective at enhancing the 77 participants' familiarity with the target phrasal verbs. However, for the 32 unexposed phrasal verbs, the results show that the semantic analysis group and the semantic analysis + image schema group scored equally well while the pairedassociate group scored lower. This may indicate that paired-associate learning is an effective approach in linking form and meaning of a holistic unit, but is limited by its strength for phrasal verbs that seem to require a semantic analysis of their component words. On the other hand, the semantic analysis and semantic analysis + image schema groups focused on learning the prototypical meanings of the particles and the results seem to suggest that they were successful at applying a semantic analysis to the unexposed phrasal verbs. Although the inclusion of image schema did not contribute to learning gains for the semantic analysis + image schema group on the test, its impact on long-term retention needs to be explored. Overall, based on the effect size, and considering the time on task was the same across the groups, it seems more worthwhile for teachers to include a semantic analysis to teaching phrasal verbs than including the use of pictures.

Table I. Exposed phrasal verb gap fill test scores

\begin{tabular}{lccc}
\hline & \multicolumn{3}{c}{ Posttest } \\
\cline { 2 - 4 } Groups & $\mathrm{N}$ & Mean & SD \\
\hline Paired-associate group & 26 & 23.73 & 3.7 \\
$\begin{array}{l}\text { Semantic analysis } \\
\text { group }\end{array}$ & 24 & 25.08 & 3.3 \\
$\begin{array}{l}\text { Semantic analysis }+ \\
\text { image schema group }\end{array}$ & 27 & 24.23 & 4.2 \\
\hline
\end{tabular}

Table 2. Unexposed phrasal verb gap fill test scores

\begin{tabular}{llcc}
\hline & \multicolumn{3}{c}{ Posttest } \\
\cline { 2 - 4 } Groups & $\mathrm{N}$ & Mean & SD \\
\hline $\begin{array}{l}\text { Paired-associate group } \\
\begin{array}{l}\text { Semantic analysis } \\
\text { group }\end{array}\end{array}$ & 26 & 15.50 & 3.4 \\
$\begin{array}{l}\text { Semantic analysis }+ \\
\text { image schema group }\end{array}$ & 27 & 20.71 & 2.8 \\
\hline
\end{tabular}




\section{References}

Boers, F., Piriz, A. M. P., \& Eyckmans, J. (2009). Does pictorial elucidation foster recollection of idioms? Language Teaching Research, 13(4), 367-382. doi:10.1177/1362168809341505

Erman, B., \& Warren, B. (2009). The idiom principle and the open choice principle. Text $\mathcal{E}$ Talk, 20(1), 29-62. doi:10.1515/ text.1.2000.20.1.29

Farsani, H. M., Moinzadeh, A., \& Tavakoli, M. (2012). Mnemonic effectiveness of CL-motivated picture-elucidation tasks in foreign learners acquisition of English phrasal verbs. Theory and Practice in Language Studies, 2(3), 498-509. doi:10.4304/tpls.2.3.498-509

Lakoff, G., \& Johnson, M. (1980). Metaphors we live by. Chicago: The University of Chicago. doi:10.3115/1118975.1118976

Rudzka-Ostyn, B. (2003). Word power: phrasal verbs and compounds. Berling: Walter De Gruyter $\mathrm{GmbH} \& \mathrm{Co}$.

Schmitt, N., Schmitt, D., \& Clapham, C. (2001). Developing and exploring the behaviour of two new versions of the Vocabulary Levels Test. Language Testing, 18(1), 55-88. doi: $10.1177 / 026553220101800103$

Side, R. (1990). Phrasal verbs: Sorting them out. ELT Journal, 44, 144-152. doi:10.1093/ elt / 44.2.144
Yasuda, S. (2010). Learning phrasal verbs through conceptual metaphors: A case of Japanese EFL learners. TESOL Quarterly, 44(2), 250-273. doi:10.5054/tq.2010.219945

This essay first appeared in Vocabulary Education \& Research Bulletin (Special Interest Group of the Japan Association for Language Teaching) 2(1), pp. 4-6. It was revised for this publication.

Brian Strong had been teaching English in Japan for over thirteen years and was an Instructor of English as a Foreign Language at Kwansei Gakuin University. He is currently a PhD student at Victoria University of Wellington, where he is researching

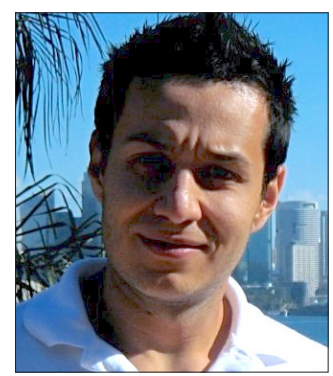
optimizing approaches to L2 instructed multiword unit acquisition. Brian looks forward to any feedback on his study. To contact him please email at $<$ strongbp@ me.com>.

\section{Learner Development SIG's 20th Anniversary Conference·LD SIG 創設20周年記念大会}

\section{Exploring Learner Development: Practices, Pedagogies, Puzzles, and Research}

- Gakushuin University, Tokyo・東京の学習院大学
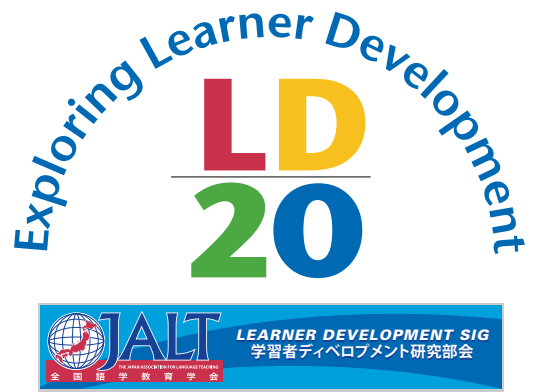

- November 23-24・11月23 24日

- Conference speakers include Naoko Aoki, Richard Smith, Kensaku Yoshida and Phil Benson・青木直子氏、リチャード・スミス氏、吉田研作氏、そしてフィル・ベンソン氏をお招 きしています。

- Early bird registration closes on September 30. More information: $<$ ldsigconference2013.org > ・早期申込割引期間は9月30日に締め切ります。詳しい情報 については、<ldsigconference2013.org>をご覧ください。 